\title{
Alexander Gerschenkron: A Personal and Fond Recollection
}

\section{HENRY ROSOVSKY}

Alexander Gerschenkron, Walter S. Barker Professor of Economics Emeritus at Harvard University, died in Cambridge, Massachusetts October 26, 1978, at the age of seventy-four. He was an influential teacher who, in his courses, introduced more than 1000 economists to economic history; his thesis students included many of the leading economic historians and Soviet specialists in the United States; as a research scholar his ideas left a major imprint on a number of fields. In this brief essay: I would like to remember the teacher, the scholar, and the man. ${ }^{1}$

Some twelve years ago, when a group of his students presented Alex ${ }^{2}$ with a Festschrift, ${ }^{3}$ we chose the following motto for the volume (from the Sayings of the Fathers): "The day is short, and the work is great, and the labourers are sluggish, and the reward is much, and the Master is urgent." There was that side to Alex. Those of us who worked closely with him always felt slightly lazy and suspected that we were underachievers. We remained perpetually awed by his work habits, knowledge, and erudition. After all, why were we either unable or unwilling to pick up Swedish or Bulgarian - before breakfast-to pursue a temporary, research interest? We always felt as though we were in the presence of someone whose level of culture and education was beyond us-and there is no doubi that, unfortunately, we were right.

But the Master was not only urgent; he was also inspiring, human, and kind. Economics 233-The Economic History of Europe - was one of the great Harvard courses for some twenty-five years. In the post-Schumpeterian era it was virtually the only course in the graduate economics curriculum that directly assaulted the provincialism of most students. They emerged from it more civilized: aware of other cultures and other times, and sensitive to the ways in which the tools of modern economic analysis could help in understanding the past. That was the real beginning of the New Economic History! The course usually enrolled over sixty students. The use of teaching fellows was disdained. He required two long term papers, which he read and returned with extensive comments-quite a few of these papers eventually were published-and each semester he insisted on a personal interview with every student to choose topics and discuss results. These interviews deserve a special word. A clumsy move in Alex's small Littauer office could precipitate a dangerous avalanche of books-I did it more than once. These and similar faux pas, however, were usually relieved by the offer of a glass of brandy at almost any time of day.

Those who wrote their dissertations with Alex came to think of him as a friend. He was as interested in us as people as he was in our intellectual development. Many of us, I believe, chose to specialize in economic history and the Soviet economy because we were attracted by his personality, by the challenge of interacting with such a powerful mind. We admired his love for and facility with his adopted language, English; some of us were puz-

Journal of Economic.History, Vol. XXXIX, No. 4 (Dec. 1979). (C) The Economic History Association. All rights reserved. ISSN 0022-0507.

The author is Dean of the Faculty of Arts and Sciences, Harvard University.

${ }^{1}$ A different version of this essay was delivered at a Memorial Service for Alexander Gerschenkron at Harvard University on December 2, 1978.

${ }^{2}$ Those, who knew Gerschenkron as a young man usually called him Shura-a Russian diminutive for Alexander.

${ }^{3}$ Henry Rosovsky, ed., Industrialization in Two Systems (New York, 1966). 
zled by his never-ending fascination with index numbers, but all of us became connoisseurs of the "Gerschenkron effect"; we were expert critics and students of his style at the podium: striding back and forth in Harvard Hall-even on Saturday mornings-adjusting the window shade an inch or so every other time.

His personal kindnesses to us were numerous and entirely in character. For example, I must have been the only soldier in Korea with a copy of Sartorius von Waltershausen's Deutsche Wirtschaftsgeschichte in my duffel bag, insistently thrust upon me by Professor Gerschenkron as suitable reading during an enforced absence from Cambridge. When I took my generals, in order to put me at ease; his first question was: "What famous figure in British economic history died by falling off a horse?" The answer was Lord Peel; I did not know it, but the twinkle in Alex's eyes did help. As a wedding present he gave me a book of chess problems inscribed with a few Pushkin verses and the counsel: "for quiet matrimonial evenings."

Most of all, however, as a teacher he'gave us his ideas and the example of his life. Alex's ideas dealt with industrialization, comparative history, relative backwardness ... and much else. Nearly all of us can trace our own ideas and inspirations in some fashion to his work. The example of his life was equally influential: a man wholly dedicated to scholarship and students - there was no slighting of either obligation. Indeed, obligation is entirely the wrong word: scholarship and students were to him such obvious pleasures.

Despite Gerschenkron's warmth and affection for colleagues and students; and his curiosity about others, he was reticent about his own life and background. Alex was born in Odessa in 1904 and left Russia with his family after the Revolution in 1920. His late teens were spent in Austria where he developed-as he told me once-a healthy dislike of the European gymnasium and a love for soccer. He studied economics and political science at the University of Vienna and graduated doctor rerum politicarum in 1928. The following decade must have been unsettled and difficult: from 1928 to 1931 he was manager of the Vienna branch of a Belgian motorcycle factory while teaching courses at the People's University; from 1931 to 1935 he was a research analyst with the Austrian Wholesale Cooperative Society; from 1937 to 1938 he was associated with the Austrian Business Cycle Research Institute.

In 1938, the year of the Anschluss, Gerschenkron and his family emigrated to the United States. There followed six years at the University of California at Berkeley doing research for himself (Bread and Democracy in Germany was published in 1943) and others, but he never succeeded in obtaining a regular ladder position. Gerschenkron's first job with long-term prospects came in 1944 when he joined the staff of the Board of Governors of the Federal Reserve System. Within two years he was the chief of the Foreign Areas Section in the Division of Research and Statistics. Finally, in 1948 he joined the Harvard economics department, from that point on his permanent home. Harvard was looking for someone who could teach both economic history and Soviet studies, and I believe that Gottfried Haberler first suggested Alex's name.

The bare facts about Gerschenkron's past never satisfied anyone who knew this man, and there developed a body of rumor and speculation to fill in missing details. It was said that the Slavic department at Harvard had offered Alex the chair in Russian literature when Roman Jakobson retired in 1960-not at all an absurd suggestion in view of his deep knowledge of the subject; that he moonlighted in Kaiser shipyards during World War II-sometimes he acknowledged this as fact. There were vague stories of adventures in Russia during the revolution, an escape to Switzerland while pursued by Nazis, and even more tantalizing hearsay concerning encounters with Marlene Dietrich and Ted Williams. (Somehow the latter was more plausible: Alex's knowledge of baseball was considerable.) Most of these stories could be true, but I do not think it useful to explore these questions more deeply at this time.

Nor can one do justice to Gerschenkron's scholarly contributions and influence in a few 
lines. But, it is possible to touch on the highlights. First of all, there was the vast range: original and major research contributions on the economic.development of Russia, Italy, France, Germany, Austria, and Bulgaria. ${ }^{4}$ In addition, a deep-one is tempted to say professional-knowledge of English, American, and Swedish economic history. Yet Gerschenkron's conceptual contributions were even more important than his dazzling range, because he was one of the great comparative historical economists of our time. Consider: the advantages of backwardness and the growth spurt; the role of the state and banks; the criticism of "prerequisites"; the previously mentioned "Gerschenkron effect" in index number theory. Each one of these subjects stimulated debate and further research. Some of them will always be associated with his name. And then there was his respected work in literary criticism: a study of Pasternak's Zhivago, a famous assault on Nabokov's performance as a translator of Pushkin, an essay on Soviet novels as a neglected source of historical information to mention only a few. There can be no doubt that Gerschenkron was a giant among economic historians and the many honors accorded to him by his peers make it clear that this is not a private judgment. ${ }^{5}$

The main theme of Gerschenkron's historical studies revolved around a question that became a powerful hypothesis and eventually a model of latecomer industrialization. The industrial revolution started in England in the eighteenth century. Before the 1820s significant industrialization had occurred in the United States, Belgium, and Switzerland. Within the next fifty years other countries joined modern economic growth, notably France, Germany, Austria, and Sweden. By the end of the nineteenth century, Russia, Japan, and Italy were beginning to experience the tremendous influences of industrialization. This story, of course, continues to unfold today well beyond the confines of Europe and North America.

In many of his writings Gerschenkron pointed to significant differences between early industrializers or pioneers ánd the latecomers or followers. The former-especially England-were relatively advanced economically and socially before the industrial revolution. By contrast, the follower countries began modern economic growth from an increasingly poorer economic and perhaps also social base. But there could be certain advantages in "relative backwardness." Pioneer countries had already made many of the necessary technological and organizational innovations opening up the possibilities of borrowing, imitation, and the use of imported skills. Mistakes might also be avoided. Could the follower countries entirely skip certain steps and develop more rapidly than their predecessors? More broadly, was there a particular pattern of growth associated with a later start-a pattern systematically related to initial conditions and the time when a country enters the race? These were the main Gerschenkronian themes. Others-notably Thorstein Veblen and Walther Hoffmann ${ }^{6}$ - had addressed similar questions, but Gerschenkron was the first to transform these themes into a historical model. It will probably remain his most lasting achievement.?

\footnotetext{
${ }^{4}$ Aside from Bread and Democracy, Gerschenkron's major books were Economic Relations with USSR (1945); A Dollar Index of Soviet Machinery Output (1951); Economic Backwardness in Historical Perspective (1962); Continuity in History and Other Essays (1968); Europe in the Russian Mirror (1970); Mercator Gloriosus and Other Essays (1973); and An Economic Spurt That Failed (1977).

${ }^{5}$ Distinguished Fellow of the American Economic Association; President of the Economic History Association; Member of the American Academy of Arts and Sciences, the American Philosophical Society, and the Swedish Academy; Corresponding member of the British Academy; Honorary Doctor of Letters, Oxford University, etc.

${ }^{6}$ See Walther G. Hoffmann, The Growth of Industrial Economies (Manchester, 1958), original German. version published in 1931; and Thorstein Veblen, Imperial Germany and the Industrial Revolution (New York, 1918).

${ }^{7}$ Gerschenkron's original statement is contained in "Economic Backwardness in Historical Perspective," in Bert F. Hoselitz, ed., The Progress of Underdeveloped Areas (Chicago, 1952).
} 
Largely based on primary research in the history of Germany and Russia, the model can be summarized in a few propositions:

1. In a relatively backward country, prior to industrialization, there is a state of tension between the actual state of economic activities and the great,promise inherent in development as seen in the more advanced countries. Tension may not occur unless certain major institutional blocks to development are removed. .In Russia this took place when serfdom was abolished in. 1861. In Germany the big event was the formation of the Zollverein in the. 1840s, which was followed by political unification.

2. From the perspective of the economically backward country, the promise of development is contained in a growing bäcklog of technological innovations produced by the more advanced industrial areas of the world. These can be borrowed without incurring the costs of pioneering; thereby making possible highër rates of economic growth in follower countries.

3. Competition from advanced countries and difficulties in creating a committed industrial labor force lead latecomers to emphasize those industries in which technological progress is particularly rapid, in other words the newest, most modern activities. In the late nineteenth and early. twentieth centuries these tended to be capital intensive: iron and steel rather than cotton textiles; producer rather than consumer goods.

. 4. Traditional views of "cheap labor" and "expensive capital" in relatively backward countries need to be revised-this is the well-known "Gerschenkron Paradox." Industrial labor, in the sense of a stable, disciplined work force divorced from the land and usable in factories may be extremely expensive in these countries, making capital a relatively cheaper factor.

5. Industrialization from a backward setting implies two kinds of bigness. First, the countries will tend to favor large units of production, and this is related to relative factor costs of labor and capital, and the nature of advanced technology. Second; there is also bigness in the sense of a sudden "revolutionary" industrial eruption. This discontinuity is not accidental: it is the result of complementarities and inadvisibilities in economic processes. Large-scale industrial development on a broad front is needed to produce the growth spurt so characteristic of countries that started modern economic growth in the second half of the last century:

6. Follower-style economic development calls for special institutions to mobilize capital. Initial requirements are too large and the pace of growth too rapid to rely on reinvested profits. In Germany, capital was mobilized by investment banks. In Russia, in the absence of an adequate banking system, the state had to perform this task.

I realize that Gerschenkron's vision is neither the perfect explanation of the past nor the ideal prediction of the future: The paradox has been questioned. Doubts have been expressed concerning the emphäsis on bigness. My own studies of Japan have attempted to show that the formation of a disciplined labor force was not a problem of the dimension envisioned by Gerschenkron. Nor did Japan favor iron and steel over cotton in the nineteenth century. Nevertheless, this is a grand and useful design that students of modern history will continue to examine with profit for many more years.

My own hope had always been that he would be the first economic historian to win the Nobel Prize in economics. ${ }^{8}$ Why? Because his writings gave us a general and consistent way of looking at European industrialization that attempted to explain the divergent experience of individual countries. Furthermore his ideas were fruitfully applicable outside of Europe, to more recent industrializers. Lastly, his model was not only confined to the simpler economic variables-institutions played a major role. At his best, Gerschenkron painted with a broad brush, but he knew the details of his canvas. He was a great Master.

Towards the end of his career in the university that he loved so much, some students and colleagues caused Alex a lot of pain. For him there were few redeeming features in the turmoil of the late 1960s and early 1970s. His own childhood and his life as a refugee had made him an unabashed American patriot, and he detested nihilism, self-indulgence, and rude behavior. He had seen too much of this in Europe. in the 1930s and he understood America far better than many: who were native born: Yet even in this.instance, Alex carried no grudges towards the younger generation: he loved to argue with students for

\footnotetext{
${ }^{8}$ Although Simon Kuznets made enormous contributions to our field, he is, I believe, more properly classified as an economist.
} 
hours and hours, and he believed that he made converts to reason. He was, perhaps understandably, less tolerant of his colleagues.

In a most peculiar way, Alex wrote his own epitaph. It was unintended. In 1952-53 he contributed an introduction to a translation of Eli Heckscher's Economic History of Sweden done in collaboration with one of his very favorite students, Goran Ohlin. Alex enormously admired the recently deceased Heckscher and said the following about him:

His immense erudition, his classical background, his modesty, his fierce independence, his willingness at all times, in the words of his beloved Horace, to step on the treacherous ashes covering the smoldering fire of conflict and controversy, and, above all, his supreme sense of duty-these qualities of a very great scholar are less readily produced by our age of anxiety and instability. To the very end he remained faithful to his mission and continued to labor in the knowledge that the night cometh when no man can work.

These are wonderful and fitting words, and apply in equal measure to Alexander Gerschenkron. 


\title{
THE
}

\section{ECONOMIC HISTORY}

\author{
ASSOCIATION
}

\section{7 \\ DIRECTORY OF MEMBERS}

\author{
Price: $\$ 2.50$ to Members; $\$ 5.00$ for Others.
}

Enclose payment with order and send to:

R. D. Williams, Treas., Box 3630

Wilmington, Del. 19807

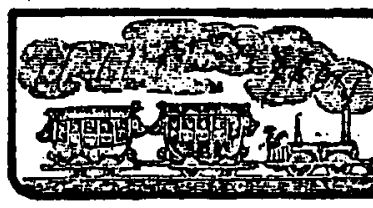

\section{? MOVING ?}

Please send changes of address for the Journal of Economic History well in advance of publication dates. To receive the March issue inform the Business Office about the change by February 15; the June issue, by May 15; the September issue, by August 15; and the December issue, by November 15 .

Due to increases in postal rates it has become necessary to levy a $\$ 1.50$ postal fee on members who did not send a change in address form in time to be included in the regular second class mailing and who wish to receive the issue which has been ransomed from the U.S. Postal Service. Members will be sent notice of issues thus returned to the Business Office.

Send changes of address to Secretary, E.H.A., Post Office Box 3630, Wilmington, Delaware 19807.

\section{? MOVING ?}

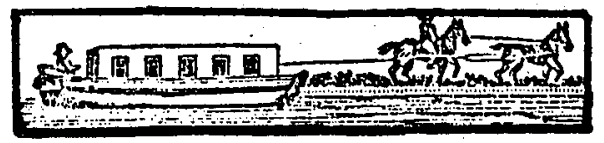

